\title{
Localization of paresthesia in patients with carpal tunnel syndrome
}

\section{Rozmieszczenie parestezji u pacjentów z zespołem kanału nadgarstka}

\author{
Piotr Puchalski , Urszula Abramczyk², Dawid Dziubiński², Wojciech Jedut² ${ }^{2}$ Andrzej Żyluk ${ }^{1 凶}$ \\ ${ }^{1}$ Pomorski Uniwersytet Medyczny w Szczecinie, Klinika Chirurgii Ogólnej i Chirurgii Ręki, ul. Unii Lubelskiej 1, 71-252 Szczecin \\ Pomeranian Medical University in Szczecin, Department of General and Hand Surgery \\ ${ }^{2}$ Pomorski Uniwersytet Medyczny w Szczecinie, Studenckie Koło Naukowe przy Klinice Chirurgii Ogólnej i Chirurgii Ręki, ul. Unii Lubelskiej 1, 71-252 Szczecin \\ Pomeranian Medical University in Szczecin, Student Scientific Circle at the Department of General and Hand Surgery \\ $\triangle$ azyluk@hotmail.com
}

\begin{abstract}
Introduction: Paresthesia (numbness, tingling, "pins and needles" sensation) and pain in the hand comprise a typical set of symptoms of carpal tunnel syndrome. Most authors consider a typical occurrence of these features within the palmar surface of digits I-IV, innervated by a compressed median nerve. Observations of patients by various authors show that some patients feel paresthesia in all digits of the affected hand and within the forearm. The objective of this study was investigation of the distribution of paresthesia in patients diagnosed with carpal tunnel syndrome, and verification of the hypothesis that this occurrence in areas beyond the innervation by the median nerve is an atypical manifestation of the syndrome.

Materials and methods: Questionnaires and notes filled out during baseline examination of 276 patients admitted to authors' institution for carpal tunnel release over a period of 1 year were reviewed. The group consisted of 211 women ( $76 \%$ ) and 65 men $(24 \%)$ at a mean age of 59 years.
\end{abstract}

Results: Two hundred seventy-four patients (99\%) reported feeling paresthesia within the involved extremity, and 2 did not, but complained of pain and reduced sensation. Most patients $140(51 \%)$ - felt paresthesia on the palmar surface of all 5 digits, including the little finger. Seventy-eight persons (28\%) reported a "typical" distribution of paresthesia within digits I-IV and 31 $(11 \%)$ in digits I-III. As many as 152 patients (55\%) felt paresthesia in the little finger, most of them being cases with numbness and tingling present in all 5 digits. The feeling of paresthesia in the midhand, close to the involved digits was reported by 158 patients (57\%).

Conclusion: We found that the distribution of symptoms in carpal tunnel syndrome does not closely match the anatomy of the median nerve and this presentation should no longer be considered atypical.

Keywords: carpal tunnel syndrome symptoms; diagnostics; paresthesia.

\begin{abstract}
ABSTRAKT
Wstęp: Parestezje (drętwienia, mrowienia, zjawisko „igły-szpilki”) i ból ręki należą do charakterystycznych objawów zespołu kanału nadgarstka. Większość autorów uważa, że typowa lokalizacja parestezji dotyczy dłoniowej powierzchni palców I-IV, które są unerwione przez uciśnięty nerw pośrodkowy. Obserwacje pacjentów z kliniki autorów wskazują, że niektórzy odczuwają parestezje na wszystkich palcach, w całej ręce i na przedramieniu. Celem pracy było zbadanie rozmieszczenia parestezji wśród pacjentów z zespołem kanału nadgarstka i weryfikacja hipotezy, że ich występowanie poza anatomicznym unerwieniem przez nerw pośrodkowy jest nietypową manifestacją kliniczną tego schorzenia.

Materiały i metody: Analizie poddano zapisy ankiet wypełnionych przy badaniu 276 pacjentów przyjętych w ciągu 1 roku do ośrodka autorów w celu leczenia operacyjnego zespołu kanału nadgarstka. W badanej grupie było 211 kobiet (76\%) i 65 mężczyzn (24\%). Średnia ich wieku wynosiła 59 lat.
\end{abstract}

Wyniki: Parestezje odczuwało 274 chorych (99\%), a 2 pacjentów nie odczuwało tego typu dolegliwości, zgłaszało natomiast ból ręki i osłabienie czucia palców. Najwięcej - 140 osób (51\%) - odczuwało je na dłoniowej powierzchni wszystkich palców, włączając palec mały. „Typowe” rozmieszczenie parestezji na palcach I-IV występowało u 78 pacjentów (28\%), a na palcach I-III u 31 (11\%). Aż 152 osoby (55\%) odczuwały parestezje w palcu małym, w większości przypadków dotyczyło to chorych, u których występowały drętwienia i mrowienia wszystkich palców. Parestezje na śródręczu, w bezpośredniej bliskości drętwiejących palców, odczuwało 158 pacjentów (57\%).

Wniosek: Uzyskane wyniki wskazują, że w zespole kanału nadgarstka parestezje często występują poza anatomicznym zakresem unerwienia przez nerw pośrodkowy i nie powinno się tego uważać za nietypowy obraz opisywanego schorzenia. Słowa kluczowe: zespół kanału nadgarstka - objawy; diagnostyka; parestezje.

\section{INTRODUCTION}

Paresthesia (numbness, tingling, "pins and needles" sensation) and pain in the hand, occurring in the night and awakening patients', comprise a typical set of symptoms of carpal tunnel syndrome (CTS). Most authors consider a typical occurrence of these features within palmar surface of I-IV digits, innervated by a compressed median nerve. Observations of patients from the authors' institution show that some patients feel paresthesia in all digits of the affected hand, as well as on the dorsal side and within the forearm, thus in an area innervated by the ulnar and radial nerves. This distribution of paresthesia 
has been considered atypical and usually prompts clinicians to extend the standard diagnostic tests for CTS, to avoid a misdiagnosis $[1,2]$. The objective of this study was an investigation of the distribution of paresthesia in patients diagnosed with CTS, and verification of the hypothesis that their occurrence in areas beyond innervation by the median nerve is an atypical manifestation of the syndrome.

\section{MATERIALS AND METHODS}

Questionnaires and notes filled out during baseline examination of 276 patients admitted to authors' institution over a period of 1 year were reviewed. The group consisted of 211 women $(76 \%)$ and 65 men $(24 \%)$ at a mean age of 59 years. The right hand was involved in 155 patients (56\%), and the left hand in 121 (44\%). One hundred and fifteen patients had bilateral syndrome and in this group the hand referred for operation was considered. Diagnosis was made on the basis of the presence of typical symptoms and signs (Tab.1). Electrophysiological tests were not required to make a confident diagnosis, but 133 patients (48\%) had done them for various reasons. In the vast majority of patients these tests were performed by the referring physician, prior to surgical referral. In all of these patients, nerve conduction studies were positive, confirming the diagnosis. A day prior to surgery, the patients were examined according to the standard protocol. Pain intensity was measured on a numeric rank scale (NRS), range o (no pain) to 10 (extreme pain), digital sensitivity with Semmes-Weinstein monofilament test, and total grip strength with a Jamar dynamometer. All patients completed the Levine questionnaire with the symptomatic and functional parts (Levine et al., 1993). Patients were asked to mark the localization of paresthesia on a diagram of the hand. As most of them did not feel tingling and numbness at the moment of examination, we relied on their recollection of the localization of the paresthesia. We divided the hand diagrams into anatomical areas that included the palmar side of each digit, the palm, the dorsal part of the hand, and the digits and forearm.

TABLE 1. Typical constellation of symptoms and signs for carpal tunnel syndrome

Pain and numbness in the hand, which awakens the patient at night. Feeling of edema of the digits

Occurrence of these symptoms in digits/hand innervated by a median nerve

Occurrence of these symptoms in the day, at manual work or static grip with flexed wrist

Relief of symptoms after shaking or rubbing the hand

Weaker grip, reduced dexterity of the hand

\section{RESULTS}

The distribution of paresthesia is shown in Table 2. Two hundred and seventy-four patients (99\%) reported feeling paresthesia within the involved extremity, and 2 did not, but complained from pain and reduced sensation. Most patients - $140(51 \%)$ - felt paresthesia on the palmar surface of all 5 digits, including the little finger. Seventy-eight patients (28\%) reported a "typical" distribution of paresthesia within digits I-IV and 31 (11\%) in digits I-III. As many as 152 patients (55\%) felt paresthesia in the little finger, most of them being cases with numbness and tingling present in all 5 digits. The feeling of paresthesia in the midhand, close to the involved digits, was reported by 158 patients (57\%).

\section{DISCUSSION}

The classical description of CTS symptoms given by the patient is of waking from sleep with a tingling or uncomfortable numbness in the hand (Tab. 1). Disturbances of sensation by paresthesia and pain are the hallmark features of CTS. Other aspects of the disease such as weakness, trophic changes and muscle wasting may be also seen in later stages of the disease, but they are less useful in diagnosis. This clinical presentation has for years been considered "classical" and its variations, i.e. the presence of symptoms in an area innervated by the ulnar or radial nerves were treated with caution and discouraged as a diagnosis of the syndrome.

Our results demonstrate that the presence of paresthesia is described by the patients more frequently in the area innervated by the median nerve, but it also occurs commonly elsewhere: $50 \%$ of the patients reported occurrences on the palmar side of all 5 digits, including the outer 2 fingers. Although sensory disturbances in CTS generally match the anatomical distribution of the median nerve, variations occur in other areas with such frequency that a diagnosis of CTS should not be excluded if the area of paresthesia does not match the classical median nerve distribution. These findings were earlier reported, but awareness of this among hand surgeons is still not enough $[1,2,3,4,5]$.

Bednarski et al. investigated the distribution of paresthesia in 39 CTS patients based on a hand diagram. Most patients described feeling these sensations in the tip of the middle finger $-95 \%$, followed by the index finger tip - 87\%, tip of the ring finger and the thumb $-79 \%$, and also in little finger tip - 51\%. In half of the patients, the paresthesia were felt on the proximal parts of these digits, on the palm $-25 \%$ and on the dorsum of the hand $-20 \%$. The authors followed-up the patients and they found that 3 months after carpal tunnel release, $30 \%$ of patients reported the presence of paresthesia in the tips of digits I-IV, and $15 \%$ in the little finger. At the 1-year follow-up, only individual patients described any slight numbness and tingling [4].

Nora et al., investigated this problem on a large cohort of 1039 patients with CTS, diagnosed on the basis of electrophysiological tests. They found that CTS patients most commonly complained of paresthesia (88\%) and pain (84\%) within the hand and forearm. In $85 \%$ of patients the occurrence matched the anatomical distribution of the median nerve, but in $79 \%$ they were present in an area of innervation by the ulnar nerve, and in 
$44 \%$ of cases in an area of innervation by the radial nerve. The authors also noticed that these 2 symptoms had a different topographical distribution, as paresthesia were restricted to the hand much more frequently than pain. Interestingly, as many as 114 patients $(11 \%)$ diagnosed with conduction abnormalities in the median nerve, had no symptoms of CTS: not paresthesia nor pain [5]. The authors of this article claim that these cases represent a subgroup of "clinically silent" CTS. This concept seems to be scientifically false, as disturbances of sensation by paresthesia and pain are the cornerstone features of CTS and the sole presence of conduction abnormalities is not. Another phenomenon has been observed, such as, patients presenting typical CTS symptoms but having normal nerve conduction studies [6]. This is not common in the clinical practice of the authors of the current study, but if so, these patients are considered ill and require adequate therapy, including surgical decompression. Nora et al., also investigated the incidence of Tinel-Hoffman's sign and Phalen test in CTS patients; the former was found positive in $34 \%$ patients whereas the latter in $56 \%$ [5]. These results are consistent with earlier studies from the authors' institution and confirm the relatively modest diagnostic value of these tests [7].

Clark et al., assessed the distribution of paresthesia, sensory disturbances and pain in 64 CTS patients. All patients reported paresthesia in the affected hand; the index finger was the most common location (94\%) followed by the middle finger ( $91 \%)$, distal palm (84\%), ring finger $(72 \%)$, thumb (69\%), thenar eminence (63\%), little finger (39\%), dorsal hand $(31 \%)$, hypothenar eminence (25\%) and forearm (13\%). Considering present standards, the distribution of paresthesia was atypical in $1 / 3$ of the patients [8].

Pain was less common than non-painful disturbances as reported in $59 \%$ of patients. Pain occurred mostly in the wrist crease $(33 \%)$, thenar eminence $(27 \%)$, forearm (20\%), middle finger $(23 \%)$, index finger $(22 \%)$, ring finger (19\%), distal palm $(16 \%)$, thumb (14\%), dorsal hand (11\%), little finger (11\%) and hypothenar eminence. A reduction of sensitivity as measured with a Semmes-Weinstein monofilament test was noted at the thenar eminence in $73 \%$ of patients, by $64 \%$ at the middle finger, $61 \%$ at the index finger, $59 \%$ at the thumb, $52 \%$ at the ring finger and $44 \%$ at the little finger. Several explanations have been proposed for the relatively frequent incidence of paresthesia in the areas of innervation by the ulnar and radial nerves, including patient error in describing the symptoms, true functional overlay, and the presence of a Martin-Gruber anastomosis (a connection between the median nerve and ulnar nerve that may exist in over $20 \%$ of individuals). It is usually unilateral. However, most likely, this pattern of distribution of paresthesia is not uncommon in many CTS patients. Therefore, the authors suggest this presentation should no longer be considered atypical [8].

The results of our work are generally consistent with those presented in literature. They confirm the objective truth that only a part of CTS patients present the "classical" pattern, as shown in Table 1. At least half of the patients demonstrate symptoms outside the median nerve distribution, which is still considered atypical by many clinicians. It seems that is enough collected evidence to no longer believe that this presentation is atypical and to raise doubts. In CTS, sensory disturbances occur most frequently in the median nerve distribution, but an atypical distribution of symptoms should not discourage a diagnosis of CTS.

TABLE 2. Description of the route, dose and time of administration for the clinical trials presented

\begin{tabular}{lccccc}
\multicolumn{2}{c}{ Variables } & \multicolumn{4}{c}{ Distribution of paresthesia } \\
\hline $\begin{array}{l}\text { Anatomical } \\
\text { area }\end{array}$ & $\begin{array}{c}\text { digits } \\
\text { I-III }\end{array}$ & $\begin{array}{c}\text { digits } \\
\text { I-IV }\end{array}$ & all digits & digit V & midhand \\
$\begin{array}{l}\text { Number of } \\
\text { patients }\end{array}$ & 31 & 78 & 140 & 152 & 158 \\
\hline$\%$ & 11 & 28 & 51 & 55 & 57 \\
\hline
\end{tabular}

\section{REFERENCES}

1. Stevens JC, Smith BE, Weaver AL, Bosch EP, Deen HG, Wilkens JA. Symptoms of 100 patients with electromyographically verified carpal tunnel syndrome. Muscle Nerve 1999;22(10):1448-56.

2. Gupta SK, Benstead TJ. Symptoms experienced by patients with carpal tunnel syndrome. Can J Neurol Sci 1997;24(4):338-42.

3. Elfar JC, Yaseen Z, Stern PJ, Kiefhaber TR. Individual finger sensibility in carpal tunnel syndrome. J Hand Surg Am 2010;35(11):1807-12.

4. Bednarski M, Żyluk A, Żyluk B. Ocena ewolucji zaburzeń czucia i dystrybucji parestezji po dekompresji kanału nadgarstka. Chir Narz Ruchu Ortop Pol 2005;70:27-32.

5. Nora DB, Becker J, Ehlers JA, Gomes I. Clinical features of 1039 patients with neurophysiological diagnosis of carpal tunnel syndrome. Clin Neurol Neurosurg 2004;107(1):64-9.

6. Witt JC, Hentz JG, Stevens JC. Carpal tunnel syndrome with normal nerve conduction studies. Muscle Nerve 2004;29(4):515-22.

7. Brüske J, Bednarski M, Grzelec H, Żyluk A. The usefulness of the Phalen test and the Hoffman-Tinel sign in the diagnosis of carpal tunnel syndrome. Acta Orthop Belg 2002;68(2):141-5.

8. Clark D, Amirfeyz R, Leslie I, Bannister G. Often atypical? The distribution of sensory disturbance in carpal tunnel syndrome. Ann R Coll Surg Engl 2011;93(6):470-3. 